\title{
Association between EcoRI fragment- length polymorphism of the immuno- globulin lambda variable 8 (IGLV8) gene family with rheumatoid arthritis and systemic lupus erythematosus
}

R.G.P. Queiroz ${ }^{1}$ M.C. Tamia-Ferreira ${ }^{1}$, I.F. Carvalho², F.C. Petean ${ }^{2}$ and G.A.S. Passos ${ }^{1,3}$
${ }^{1}$ Grupo de Imunogenética Molecular (GIM), Departamento de Genética, ${ }^{2}$ Departamento de Clínica Médica, Faculdade de M edicina de Ribeirão Preto, and ${ }^{3} \mathrm{D}$ isciplina de Genética (DMEF), Faculdade de $\mathrm{O}$ dontologia de Ribeirão Preto, Universidade de São Paulo, Ribeirão Preto, SP, Brasil

\section{Correspondence \\ G.A.S. Passos \\ Grupo de Imunogenética Molecular Departamento de Genética \\ FMRP, USP \\ 14040-900 Ribeirão Preto, SP \\ Brasil \\ Fax: + 55-16-633-0069 \\ E-mail: passos@rge.fmrp.usp.br}

Research supported by FAPESP (Nos. 98/05584-9 and 98/09789-4). R.G.P. Q ueiroz and M.C.

Tamia-Ferreira are recipients of CAPES and CNPq fellowships, respectively.

Received August 10, 2000 Accepted February 6, 2001

\section{Abstract}

The human immunoglobulin lambda variable 8 (IGLV8) subgroup is a gene family containing three members, one of them included in a monomorphic 3.7-kb EcoRI genomic fragment located at the major lambda variable locus on chromosome 22q11.1 (gene IGLV8a, EMBL accession No. Z73650) at $100 \%$ frequency in the normal urban population. The second is a polymorphic RFLP allele included in a $6.0-\mathrm{kb}$ EcoRI fragment at $10 \%$ frequency, and the third is located in a monomorphic $8.0-\mathrm{kb}$ EcoRI fragment at $100 \%$ frequency, the last being translocated to chromosome $8 \mathrm{q} 11.2$ and considered to be an orphan gene. Our Southern blot-EcoRI-RFLP studies in normal individuals and in patients with rheumatoid arthritis (RA) or with systemic lupus erythematosus (SLE), using a specific probe for the IGLV8 gene family (probe pVL8, EMBL accession No. X75424), have revealed the two monomorphic genomic fragments containing the IGLV8 genes, i.e., the 3.7-kb fragment from chromosome $22 \mathrm{q} 11.1$ and the $8.0-\mathrm{kb}$ fragment from $8 \mathrm{q} 11.2$, both occurring at $100 \%$ frequency $(103$ normal individuals, 48 RA and 28 SLE patients analyzed), but absence of the $6.0-\mathrm{kb}$ IGLV8 polymorphic RFLP allele in all RA or SLE patients. As expected, the frequency of the $6.0-\mathrm{kb}$ allele among the normal individuals was $10 \%$. These findings suggest an association between the absence of the $6.0-\mathrm{kb}$ EcoRI fragment and rheumatoid arthritis and systemic lupus erythematosus.

The human immunoglobulin lambda light chains contribute about $40 \%$ to the functional serum antibodies, indicating the important role played by these chains in the antibody response (1). The immunoglobulin lambda variable (IGLV) locus extends about $800 \mathrm{~kb}$ on chromosome 22q11.1-11.2 and has
Key words

- Rheumatoid arthritis

- Systemic lupus

erythematosus

- Human V-lambda 8 genes

- Polymorphism of

$\mathrm{V}$-lambda genes

- RFLP-disease association been mapped and fully sequenced by contig methodology locating all the known functional V-lambda genes and pseudogenes (2-5).

We know the positions of about 70 germline V-lambda sequences of which 3033 are functional V-lambda genes distributed into 11 IGLV gene families (IGLV1- 
IGLV11) (2-5).

The V-lambda genes are associated with $E c o$ RI site-flanked genomic fragments detectable in Southern blots of genomic DNA samples $(2,6,7)$.

An orphan gene belonging to the IGLV8 family translocated from the major IGLV locus on chromosome 22q11.1 to chromosome $8 \mathrm{q} 11.2$ was recently described, and there is evidence that its expression is associated with the manifestation of autoimmune diseases (8-10).

Rheumatoid arthritis (RA) is a heterogeneous systemic rheumatic disease of unknown etiology affecting synovial membranes of the joints, with both environmental and genetic factors contributing to its manifestation (11).

Systemic lupus erythematosus (SLE) is a disease also of unknown etiology characterized by inflammation in many different organ systems associated with the production of antibodies reactive with nuclear (DNA and RNA), cytoplasmic and cell membrane antigenic determinants (12).

We evaluated the polymorphism of the IGLV8 gene family in patients with RA or with SLE and normal individuals from an urban Brazilian population in the Ribeirão Preto region, São Paulo State, southeastern Brazil, by Southern hybridization.

A total of 48 RA (36 women and 12 men) and 56 SLE patients ( 52 women and 4 men) fulfilling the American College of Rheumatology criteria for RA (13) and 103 normal individuals (71 women and 32 men) were studied. The study was approved by the Ethics Committee of Hospital das Clínicas de Ribeirão Preto, USP (No. 4953/98).

Among the 103 normal individuals analyzed (71 women and 32 men) we demonstrated the monomorphic $8.0-$ and $3.7-\mathrm{kb}$ EcoRI fragments at $100 \%$ frequency and the $6.0-\mathrm{kb}$ EcoRI fragment at 10\% frequency (for both male and female groups) corroborating our previous observations (6) (Figure 1A).

In contrast, we were not able to demon- strate the polymorphic $6.0-\mathrm{kb}$ EcoRI fragment in RA and SLE patients (Figure 1B and C). The absence of the $6.0-\mathrm{kb}$ allele in the tested population of autoimmune patients is significantly different from the $10 \%$ incidence in the normal group as evaluated by statistical analysis by the chi-square test $(\alpha=0.05, P=0.0136)$.

There are some known IGLV genes whose EcoRI fragments migrate between 5.7 and $6.5 \mathrm{~kb}$ and others whose EcoRI fragments migrate between 7.5 and $8.6 \mathrm{~kb}(2)$.

Our restriction fragment-length polymorphism (RFLP) studies of the different IGLV gene families in the Brazilian population, including the same normal individuals analyzed here, revealed that these fragments are highly polymorphic, including deletions (data not shown).

The present results clearly show that the $8.0-\mathrm{kb} E c o \mathrm{RI}$ band is present in $100 \%$ of the individuals analyzed in a monomorphic fashion.

The IGLV7a gene (EMBL accession No. Z73659) migrates in an EcoRI fragment of $7.9 \mathrm{~kb}$, but it has only $66 \%$ sequence identity with the pVL8 probe. Considering that our Southern membranes were submitted to highstringency washes, it is unlikely that they remained cross-hybridized with the IGLV7a gene after the washes.

The IGLV9S1 gene is a sequence-tagged site for the IGLV locus and migrates in a 5.6$\mathrm{kb} E c o$ RI fragment. Our previous RFLP studies showed that it is present in $100 \%$ of individuals from different populations $(7,14)$. The 6.0-kb EcoRI band detected with the pVL8 probe was present in $10 \%$ of the normal individuals and absent in the RA or SLE patients analyzed.

Further studies are being done in our laboratory to survey the expression of the IGLV8 allele present in the $6.0-\mathrm{kb} E c o$ RI fragment and to evaluate a possible functional significance with regard to the clinical status of the RA or SLE patients.

We have polymorphism and/or sequence 
A

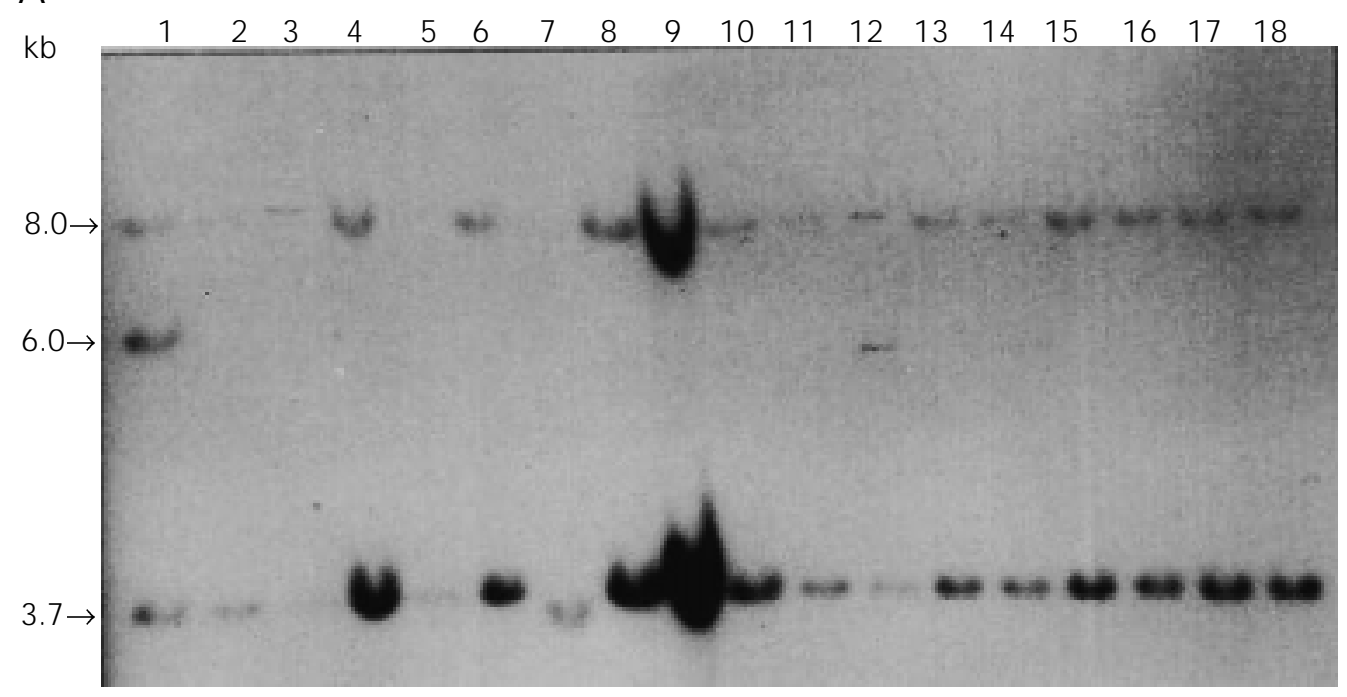

B

$\mathrm{kb}$

\begin{tabular}{lllllll}
1 & 2 & 3 & 4 & 5 & 6 & 7 \\
\hline
\end{tabular}
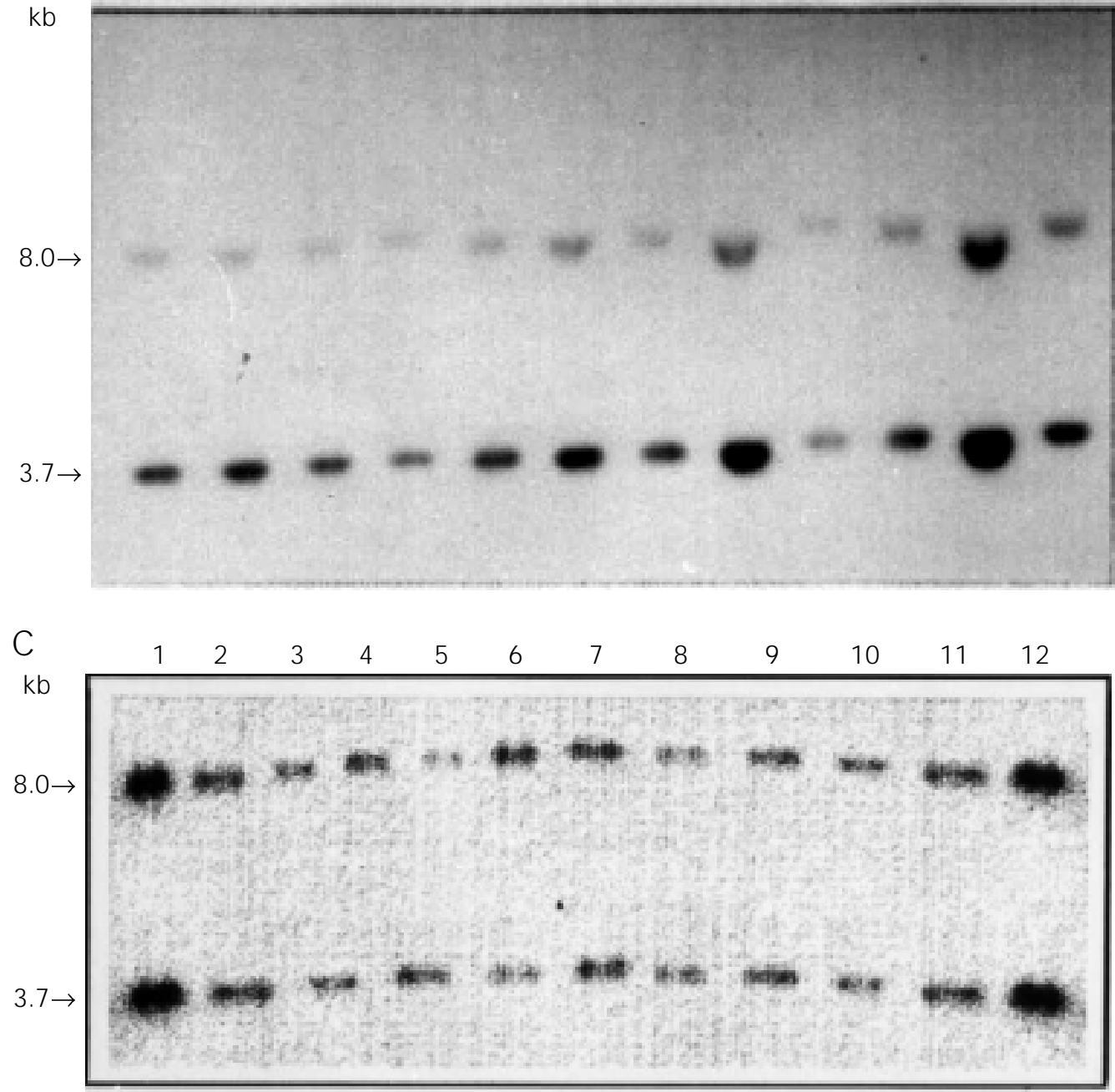

Figure 1 - Southern blots of genomic DNA samples digested with EcoRI and hybridized with the pVL8 probe. All samples from the normal individuals presented the 8.0- and $3.7-\mathrm{kb}$ monomorphic fragments and the $6.0-\mathrm{kb}$ polymorphic fragment (10\% frequency) (A). The samples from rheumatoid arthritis (B) and systemic lupus enythematosus (C) patients presented only the 8.0- and 3.7-kb monomorphic fragments. Hybond $\mathrm{N}+$ membranes (Amersham Pharmacia Biotech, Little Chalfont, England) were washed under high-stringency conditions (typical results). 
homology evidence suggesting that we can detect the members of the IGLV8 gene family and establish an association between the absence of the 6.0-kb EcoRI IGLV8 fragment RFLP allele and rheumatoid arthritis or systemic lupus erythematosus.

\section{Acknowledgments}

We thank Dr. E.A. Donadi for help and discussions, MSc Renato Sousa Cardoso for statistical analysis, and Mr. Sávio E.F. Miranda for technical assistance (FAPESP fellow No. 99/09051-8).

\section{References}

1. Padlan E (1994). Anatomy of the antibody molecule. Molecular Immunology, 31: 169-217.

2. Frippiat J -P, Williams SC, Tomlinson IM, Cook GP, Cherif D, Le Paslier D, Collins J E, Dunham I, Winter G \& Lefranc M-P (1995). Organisation of the human immunoglobulin lambda light-chain locus on chromosome 22q11.2. Human Molecular Genetics, 4: 981-983.

3. Kawasaki K, Minoshima S, Schooler K, Kudoh J, Asakawa S, de J ong PJ \& Shimizu N (1995). The organisation of the human immunoglobulin $\lambda$ gene locus. Genome Research, 5: 125-135.

4. Kawasaki K, Minoshima S, Nakato E, Shibuia K, Shintani A, Schmeits J L, Wang J \& Shimizu N (1997). One-megabase sequence analysis of the human immunoglobulin lambda gene locus. Genome Research, 7: 250-261.

5. Passos GAS \& Lefranc M-P (1997). A 37$\mathrm{kb}$ restriction map of the human immunoglobulin lambda variable locus, VB cluster, harboring four functional genes and two non-coding $v \lambda$ sequences. Brazilian J ournal of Genetics, 20: 725-730.
6. Passos GAS, Queiroz RGP \& Brûlé A (1997). EcoRI restriction fragment-length polymorphism of the human immunoglobulin variable lambda 8 (IGLV8) subgroup reveals a gene family. Human Immunology, 55: 96-102.

7. Silva MI \& Passos GAS (1999). The human immunoglobulin variable lambda locus IGLV9 gene is a monomorphic marker in the urban Brazilian population. Immunology Letters, 69: 369-370.

8. Frippiat J -P, Dard P, Marsh S, Winter G \& Lefranc M-P (1997). Immunoglobulin lambda light chain orphans on human chromosome 8q11.2. European J ournal of Immunology, 27: 1260-1265.

9. Queiroz RGP, Carrier A, Victorero G, J ordan B \& Passos GAS (1997). Chromosomal location of the human immunoglobulin lambda variable 8 (IGLV8) gene family outside the major $\lambda$ locus on chromosome 22q11.2. Immunology Letters, 59: 177180.

10. Lee G, Ware RR \& Latov N (1994). Somatically mutated member of the human V V VIII gene family encodes anti-myelinassociated glycoprotein (MAG) activity.
J ournal of Neuroimmunology, 51: 45-52.

11. Deighton CM \& Walker DJ (1991). The familial nature of rheumatoid arthritis. Annals of the Rheumatic Diseases, 50: 6265.

12. Hahn BH (1997). Pathogenesis of systemic lupus erythematosus. In: Kelley WN, Harris ED, Ruddy S \& Sledge C (Editors), Textbook of Rheumatology. 5th edn. WB Saunders, Philadelphia.

13. Arnett FC, Edworthy SM, Bloch DA, McShane DJ , Fries J F, Cooper NS, Healey LA, Kaplan SR, Liang MH, Luthra HS, Medsger TA, Mitchell DM, Neustadt DH, Pinals RS, Schaller J G, Sharp J T, Wilder RL \& GG Hunder (1988). The American Rheumatism Association 1987 revised criteria for the classification of rheumatoid arthritis. Arthritis and Rheumatism, 31: 315-324.

14. Passos GAS, Frippiat J -P \& Lefranc M-P (1994). Definition of a sequence-tagged site for the human immunoglobulin IGLV9S1 gene located at chromosome 22q11. Experimental and Clinical Immunogenetics, 11: 222-226. 